\title{
4: 89735485-89784497
}

National Cancer Institute

\section{Source}

National Cancer Institute. 4:89735485-89784497. NCI Thesaurus. Code C41949.

Physical location of CEB1_Gene 